\title{
PENGARUH REWARD DAN PUNISHMENT TERHADAP MOTIVASI KERJA KARYAWAN PADA CV AYUDYA TABANAN BALI
}

\author{
G.A.A.I. Pradnyani ${ }^{1}$, P.I. Rahmawati ${ }^{2}$, N.M. Suci ${ }^{3}$ \\ 1,2,3Jurusan Manajemen, Universitas Pendidikan Ganesha, Singaraja \\ e-mail: ayuintan210298@gmail.com, putuindah.undiksha@gmail.com, madesuci_bali@yahoo.com
}

\begin{abstract}
Abstrak
Penelitian ini bertujuan untuk menguji pengaruh reward dan punishment terhadap motivasi kerja baik secara parsial maupun simultan. Adapun subjek dalam penelitian ini adalah karyawan yang bekerja di CV Ayudya Tabanan Bali, sedangkan objek dalam penelitian ini adalah reward, punishment, dan motivasi kerja. Populasi dalam penelitian ini adalah seluruh karyawan CV Ayudya Tabanan Bali yang berjumlah 31 orang. Penelitian ini menggunakan metode kuantitatif. Teknik pengumpulan data pada penelitian ini yaitu menggunakan kuesioner. Selanjutnya, data dianalisis menggunakan analisis regresi linear berganda. Hasil penelitian menunjukkan bahwa ada pengaruh positif dan signifikan dari reward dan punishment terhadap motivasi kerja baik secara parsial maupun simultan. Penelitian ini juga menunjukkan bahwa kontribusi dari reward dan punishment terhadap motivasi kerja sebesar $54,2 \%$, sisanya sebesar $45,8 \%$ dijelaskan oleh variabel lain diluar penelitian ini.
\end{abstract}

Kata kunci: Motivasi, Punishment, Reward

\begin{abstract}
This study aims to examine the effect of reward and punishment on work motivation both partially and simultaneously. The subjects in this study were employees who worked at CV Ayudya Tabanan Bali, while the objects in this study were reward, punishment, and work motivation. The population in this study were all employees of CV Ayudya Tabanan Bali, amounting to 31 people. This study used quantitative method. The data collection technique in this research is questionnaire. Futhermore, the data analyzed using multiple linear regression analysis. The results showed there was a positive and significant effect of reward and punishment on job motivation partially and simultaneously. This study also shows that the contribution of reward and punishment to work motivation is $54.2 \%$, the remaining $45.8 \%$ is explained by another variable which excluded in this model.
\end{abstract}

Keywords : Motivation, Punishment, Reward

\section{Pendahuluan}

Era globalisasi menciptakan banyak sekali persaingan dan kemajuan termasuk dalam bidang perekonomian. Salah satu dampak besar globalisasi bagi dunia usaha adalah maraknya perusahaan-perusahaan yang bersaing ketat untuk memperoleh pangsa pasar yang mereka targetkan. Maka dari itu, segala bentuk aspek keunggulan sangat dibutuhkan oleh perusahaan untuk menciptakan daya saing, mencapai tujuan, dan memajukan usahanya. Sebagai upaya untuk menghadapi semua tantangan, hambatan, serta perubahan-perubahan yang terjadi akibat globalisasi, maka sebuah perusahaan ataupun organisasi memerlukan potensi atau kekuatan internal yang bersifat kokoh. Hal ini karena perusahaan yang ingin berkembang dan maju, harus mampu mengatasi setiap persoalan dengan solusi yang tepat sesuai situasi dan juga kondisi yang tengah dihadapi.

Keberhasilan perusahaan dalam mencapai tujuan dipengaruhi oleh beberapa faktor, salah satu faktor penting adalah sumber daya manusia (Kentjana \& Nainggolan, 2018). Pernyataan tersebut mencerminkan bahwa sumber daya manusia diyakini memegang peranan vital dalam organisasi/ perusahaan. Berhasil atau tidaknya suatu perusahaan dalam mencapai tujuan bukan hanya tergantung pada kecanggihan teknologi yang dimiliki, banyaknya dana operasi yang dimiliki, sarana dan prasarana yang memadai, tetapi juga tergantung pada aspek sumber daya manusia yang ada di dalam perusahaan tersebut. Jika perusahaan mengupayakan sumber daya manusia yang berkualitas tentu mereka juga akan menunjukkan kontribusinya untuk memajukan perusahaan.

Mengingat pentingnya peran sumber daya manusia bagi kelangsungan operasional perusahaan, maka setiap perusahaan sebaiknya memiliki program-program yang mampu 
dijadikan alat untuk meningkatkan kualitas sumber daya manusianya. Perusahaan pada umumnya menerapkan banyak program SDM, namun tidak semua program diyakini mampu meningkatkan kualitas sumber daya manusianya. Meskipun perusahaan sudah memiliki visi dan misi yang cemerlang, struktur organisasi yang baik, maupun jobdesk yang jelas, tetapi perusahaan tetap harus meningkatkan kualitas sumber daya manusianya. Hal yang mampu meningkatkan kualitas sumber daya manusia adalah dengan cara meningkatkan motivasi kerja karyawan itu sendiri (Prasetya, 2017).

Motivasi kerja adalah sesuatu yang menimbulkan dorongan atau semangat kerja (Manullang 2008:166). Motivasi kerja adalah kekuatan pendorong yang mampu mengarahkan perilaku seseorang dalam upaya mencapai tujuan organisasi (Farianda, 2013). Apabila karyawan memiliki motivasi dalam bekerja, maka semangat kerja karyawan juga akan meningkat. Meningkatnya semangat kerja diyakini akan membuat karyawan tersebut semakin produktif dalam bekerja. Jika karyawan dalam perusahaan mampu bekerja secara maksimal, maka perusahaan atau organisasi tersebut akan mampu mencapai tujuan. Adapun indikator motivasi yaitu prestasi kerja, keahlian, dan kemampuan dalam menyelesaikan tugas (Triyanto \& Sudarwati, 2014). Faktor yang mempengaruhi motivasi individu adalah melalui pemberian penghargaan (reward) dan hukuman (punishment) kepada karyawan (Fajar, 2018).

Reward adalah penghargaan atau balas jasa yang diberikan oleh perusahaan terhadap karyawannya yang berprestasi atau menunjukkan kinerja sesuai dengan yang diharapkan perusahaan (Sandy \& Faozen, 2017). Reward adalah sebuah metode yang digunakan untuk membuat seseorang termotivasi melakukan hal baik dan meningkatkan prestasi (Yuni, 2013). Sistem reward merupakan hal penting karena mendorong tercapainya hasil yang diinginkan dan memotivasi karyawan untuk mencapai dan melebihi target dalam bekerja (Merchant \& Stede dalam Kentjana \& Nainggolan, 2018). Reward diukur dengan indikator intrinsic reward dan ekstrinsic reward (Edirisooriya dalam Kentjana \& Nainggolan, 2018).

Adanya reward akan menimbulkan gairah dan semangat untuk bekerja (Farianda, 2013). Sehingga jika karyawan sudah merasakan gairah dan semangat tersebut dari dalam dirinya, otomatis karyawan akan termotivasi untuk meningkatkan produktivitas dan menunjukkan kinerja terbaik saat bekerja. Hal tersebut akan sangat baik dampaknya bagi perusahaan, karena karyawan yang produktif akan dapat membantu perusahaan untuk mencapai tujuan. Terdapat pengaruh antara reward terhadap motivasi kerja. Dari hasil kajian empiris, dibuktikan bahwa intrinsic reward mempunyai pengaruh positif dan signifikan terhadap motivasi kerja karyawan (Maria, 2010; Winangsih, 2017). Kajian empiris lainnya juga menemukan bahwa penghargaan/ reward berpengaruh positif dan signifikan terhadap motivasi kerja (Sari, 2014; Fatmawati, 2016; Pratama, 2017; Wirawan \& Afani, 2018; Kentjana \& Nainggolan, 2018; Isnainy \& Nugraha, 2018). Berdasarkan pemaparan di atas, maka dapat dirumuskan hipotesis sebagai berikut:

$\mathrm{H}_{1}$ : Ada pengaruh reward terhadap motivasi kerja karyawan pada CV Ayudya Tabanan Bali.

Punishment adalah hukuman yang diberikan kepada karyawan karena telah melakukan pelanggaran terhadap aturan yang berlaku (Sandy \& Faozen, 2017). Indikator punishment yaitu tata tertib, larangan, disiplin, teguran, dan hukuman (Purwanto dalam Sari, 2014). Punishment yang diberikan secara tepat dan bijak bisa menjadi alat perangsang bagi karyawan untuk meningkatkan motivasi kerja (Pratama, 2017).

Punishment yang diberikan umumnya memiliki tujuan baik agar para karyawan yang lalai dalam bekerja akan sadar dengan kesalahannya dan berusaha memperbaiki cara kerja yang salah. Punishment diharapkan akan mengarahkan/mendidik karyawan kepada perilaku positif dan mendorong adanya motivasi kerja (Sari, 2014). Terdapat pengaruh antara punishment dengan motivasi kerja. Semakin tinggi punishment, maka motivasi kerja akan semakin tinggi, dan sebaliknya jika punishment rendah, maka motivasi kerja akan menurun. Pendapat tersebut didukung oleh hasil kajian empiris oleh Sari (2014), Pratama (2017), Wirawan \& Afani (2018), Kentjana \& Nainggolan (2018) yang membuktikan punishment 
berpengaruh positif dan signifikan terhadap motivasi kerja karyawan. Berdasarkan pemaparan di atas, maka dapat dirumuskan hipotesis sebagai berikut:

$\mathrm{H}_{2}$ : Ada pengaruh punishment terhadap motivasi kerja karyawan pada CV Ayudya Tabanan Bali.

Reward dan punishment adalah dua kata yang saling bertolak belakang akan tetapi, kedua hal tersebut saling berkaitan, keduanya memotivasi karyawan untuk meningkatkan kualitas kinerja (Kentjana \& Nainggolan, 2018). Pemberian reward dan punishment tidak bisa diberikan sembarangan atau tanpa alasan yang rasional.

Maka dari itu, perusahaan harus memiliki mekanisme pemberian reward dan punishment yang jelas untuk para karyawannya. Hal itu perlu dilakukan agar pemberian reward maupun punishment tidak salah sasaran dan adil bagi karyawan sehingga karyawan dan perusahaan dapat merasakan dampak positif dari adanya reward dan punishment tersebut. Umumnya reward diberikan berdasarkan penilaian kinerja, prestasi kerja, maupun kontribusi karyawan yang bersangkutan dalam meningkatkan omzet perusahaan. Sedangkan punishment yang berupa hukuman diberikan kepada karyawan yang lalai dalam menjalankan kewajiban bekerja.

Jika reward dan punishment dilakukan secara beriringan dengan tepat dan adil, maka dampak positif akan dapat dirasakan oleh perusahaan, mulai dari meningkatnya kedisiplinan para karyawan hingga meningkatnya motivasi kerja yang mampu mendorong karyawan untuk bekerja dengan lebih produktif. Terdapat pengaruh antara reward dan punishment secara bersama-sama terhadap motivasi kerja. Semakin tinggi reward dan punishment, maka semakin tinggi motivasi kerja. Semakin rendah reward dan punishment, maka semakin rendah pula motivasi kerja karyawan. Pendapat tersebut didukung oleh hasil kajian empiris oleh Pratama (2017), Sandy \& Faozen (2017), Wirawan \& Afani (2018), Fajar (2018), Kentjana \& Nainggolan, (2018) yang membuktikan bahwa reward dan punishment berpengaruh positif terhadap motivasi kerja. Dari pemaparan di atas, maka dapat dirumuskan hipotesis sebagai berikut:

$\mathrm{H}_{3}$ : Ada pengaruh reward dan punishment terhadap motivasi kerja karyawan pada CV Ayudya Tabanan Bali.

CV Ayudya Tabanan Bali merupakan sebuah usaha industri pengolahan daging (meat processing) yang telah berdiri sejak tahun 2001. Dalam menjalankan operasionalnya, perusahaan ini tidak luput dari permasalahan terkait kualitas sumber daya manusianya. Berdasarkan observasi awal di CV Ayudya Tabanan Bali, terungkap bahwa terdapat permasalahan dalam perusahaan tersebut yang disebabkan oleh masih rendahnya motivasi kerja karyawan dalam bekerja.

Adapun berbagai fenomena rendahnya motivasi kerja karyawan CV Ayudya Tabanan Bali antara lain, sebagian besar karyawan belum mampu menyelesaikan tugas dengan cepat sesuai target yang telah ditentukan oleh perusahaan. Masalah lainnya adalah banyak karyawan yang sering terlambat masuk kerja dan juga terlambat kembali setelah jam istirahat. Selain itu, karyawan kurang inisiatif dalam bekerja. Jika ada kendala dalam pekerjaan mereka, karyawan hanya menunggu solusi dari atasan tanpa berusaha proaktif dan membantu mencari pemecahan masalah.

Selain itu, berdasarkan observasi awal peneliti menduga bahwa sistem punishment yang berjalan di CV Ayudya Tabanan Bali belum efektif dikarenakan banyaknya karyawan yang melakukan pelanggaran berulang kali, seperti terlambat bekerja. Berdasarkan wawancara dengan beberapa karyawan yang bekerja di CV Ayudya Tabanan Bali, peneliti juga memperoleh informasi bahwa diduga yang menyebabkan rendahnya motivasi karyawan di CV Ayudya Tabanan Bali dalam bekerja dikarenakan sistem pemberian reward dalam bentuk gaji maupun bonus yang tidak tepat waktu dan tidak konsisten. Berdasarkan uraian permasalahan di atas, maka perlu dilakukan penelitian pada CV Ayudya Tabanan Bali dengan judul "Pengaruh Reward dan Punishment terhadap Motivasi Kerja Karyawan pada CV Ayudya Tabanan Bali”.

Berdasarkan latar belakang di atas, dapat dirumuskan permasalahan sebagai berikut: (1) Bagaimana pengaruh reward terhadap motivasi kerja karyawan pada CV Ayudya 
Tabanan Bali? (2) Bagaimana pengaruh punishment terhadap motivasi kerja karyawan pada CV Ayudya Tabanan Bali? (3) Bagaimana pengaruh reward dan punishment terhadap motivasi kerja karyawan pada CV Ayudya Tabanan Bali?

Adapun tujuan dari penelitian ini adalah: (1) Untuk mengetahui pengaruh reward terhadap motivasi kerja karyawan pada CV Ayudya Tabanan Bali. (2) Untuk mengetahui pengaruh punishment terhadap motivasi kerja karyawan pada CV Ayudya Tabanan Bali. (3) Untuk mengetahui pengaruh reward dan punishment terhadap motivasi kerja karyawan pada CV Ayudya Tabanan Bali.

Manfaat dalam penelitian ini meliputi manfaat teoritis dan manfaat praktis. Adapun manfaat teoritis dalam penelitian ini adalah hasil penelitian ini diharapkan dapat dijadikan bahan untuk mengembangkan ilmu dan teori ekonomi, khususnya manajemen sumber daya manusia. Sedangkan manfaat praktisnya yaitu penelitian ini diharapkan dapat memberi sumbangan pemikiran bagi pemilik CV Ayudya Tabanan Bali dalam menjalankan program reward serta punishment untuk karyawan pada perusahaannya sehingga nantinya dapat meningkatkan motivasi karyawannya dalam bekerja. Bagi Peneliti, penelitian ini digunakan untuk menambah pengetahuan dan pemahaman mengenai manajemen sumber daya manusia secara riil khususnya tentang reward, punishment, dan motivasi kerja karyawan dalam sebuah organisasi atau perusahaan. Bagi Universitas Pendidikan Ganesha, penelitian ini dapat menambah koleksi pustaka untuk bahan bacaan dan kajian mahasiswa Universitas Pendidikan Ganesha.

\section{Metode}

Penelitian yang digunakan adalah penelitian kuantitatif. Variabel yang dilibatkan dalam penelitian ini adalah satu variabel terikat yaitu motivasi kerja, serta dua variabel bebas yaitu reward dan punishment. Adapun subjek dalam penelitian ini adalah karyawan yang bekerja di CV Ayudya Tabanan Bali. Objek dalam penelitian ini adalah Reward $\left(\mathrm{X}_{1}\right)$, Punishment $\left(\mathrm{X}_{2}\right)$, dan Motivasi kerja $(\mathrm{Y})$.

Populasi penelitian merupakan seluruh objek yang ingin diteliti di dalam sebuah penelitian (Suliyono, 2010:22). Populasi dari penelitian ini adalah seluruh karyawan pada CV Ayudya Tabanan Bali yang berjumlah 31 orang. Jenis data yang dikumpulkan dalam penelitian ini adalah data kuantitatif yang bersumber dari data primer yang dikumpulkan dengan metode kuesioner.

Setelah data berhasil dikumpulkan, perlu dilakukan uji asumsi klasik yang meliputi uji normalitas, uji multikolinearitas, dan uji heterokesdastisitas. Karena data yang baik adalah data yang residualnya terdistribusi normal, tidak terjadi multikolinearitas, dan tidak terjadi heterokesdastisitas (Purnomo, 2016). Setelah itu, untuk menguji kebenaran hipotesis dari data kuantitatif tersebut kemudian dilakukan analisis dengan menggunakan teknik analisis regresi linear berganda dengan menggunakan program SPSS 23 for Windows. Model analisis regresi linear berganda mengasumsikan adanya hubungan linear antara variabel terikat dengan masing-masing variabel bebasnya (Janie, 2012:13). Skala ukur yang digunakan adalah skala ordinal. Dari hasil analisis regresi linear berganda tersebut kemudian dilakukan uji $t$ untuk menguji pengaruh parsial dan uji $F$ untuk menguji pengaruh simultan serta uji koefisien determinasi untuk mengukur seberapa besar kemampuan variabel reward dan punishment dalam menerangkan variabel motivasi kerja.

\section{Hasil dan Pembahasan Hasil}

Model analisis yang digunakan dalam penelitian ini adalah analisis regresi linear berganda. Teknik analisis ini digunakan untuk mencari ada atau tidaknya pengaruh variabel bebas yaitu reward dan punishment terhadap motivasi kerja karyawan pada CV Ayudya Tabanan Bali dengan bantuan program aplikasi komputer Statistical Package for Social Science (SPSS) version 23 for Windows. 
Berikut merupakan ringkasan dari hasil output aplikasi SPSS terkait pengujian pengaruh reward dan punishment terhadap motivasi kerja yang dapat dilihat pada Tabel $1 \mathrm{di}$ bawah ini.

Tabel 1.

Hasil Regresi Linear Berganda

\begin{tabular}{lcc}
\hline Variabel Independen & Variabel Dependen: Motivasi kerja \\
\hline & Koefisien Regresi & t hitung \\
\hline Reward $\left(\mathrm{X}_{1}\right)$ & 0,340 & $3,541(P$-value $=0,001)$ \\
Punishment $\left(\mathrm{X}_{2}\right)$ & 0,370 & $3,268(P$-value $=0,003)$ \\
\hline Konstanta & 3,138 & \\
Adjusted $R^{2}$ & 0,542 & \\
F hitung & 18,771 & $(P$-value $=0,000)$ \\
\hline
\end{tabular}

Berdasarkan hasil analisis pada Tabel 1, dapat dibuat persamaan regresi untuk menggambarkan pengaruh reward dan punishment terhadap motivasi kerja karyawan pada CV Ayudya Tabanan Bali, yaitu sebagai berikut:

$\mathrm{Y}=3,138+0,340 \mathrm{X}_{1}+0,370 \mathrm{X}_{2}+\mathrm{e}$

Arti persamaan regresi di atas adalah sebagai berikut: Konstanta sebesar 3,138 menyatakan bahwa jika variabel independen (reward dan punishment) dianggap konstan, maka rata-rata motivasi kerja sebesar 3,138 poin/skor. Koefisien regresi reward sebesar 0,340 menyatakan bahwa setiap peningkatan nilai reward sebesar satu satuan, maka akan meningkatkan motivasi kerja sebesar 0,340. Koefisien regresi punishment sebesar 0,370 menyatakan bahwa setiap peningkatan nilai punishment sebesar satu satuan, maka akan meningkatkan motivasi kerja sebesar 0,370.

Diketahui koefisien regresi dari variabel reward adalah sebesar 0,340, sehingga dapat dikatakan bahwa reward berpengaruh positif terhadap motivasi kerja. Untuk mengetahui signifikan atau tidaknya pengaruh itu, maka selanjutnya dilakukan uji t. Hasil pengujian hipotesis menunjukkan bahwa nilai t variabel reward sebesar 3,541 dengan $P$ value (sig) sebesar 0,001 di mana nilai $P$-value tersebut lebih kecil dari taraf signifikansi yang ditentukan yaitu $0,05(0,001<0,05)$ sehingga menunjukkan bahwa nilai $t$ yang diperoleh tersebut signifikan. Maka berdasarkan uji t diperoleh hasil bahwa reward $\left(\mathrm{X}_{1}\right)$ berpengaruh positif dan signifikan terhadap motivasi kerja (Y). Hal ini berarti bahwa semakin baik atau seringnya reward yang diberikan kepada karyawan CV Ayudya, maka akan semakin meningkatkan motivasi kerja karyawan tersebut.

Diketahui koefisien regresi dari variabel punishment adalah sebesar 0,370 sehingga dapat dikatakan bahwa punishment berpengaruh positif terhadap motivasi kerja. Untuk lebih mengetahui signifikan atau tidaknya pengaruh tersebut, maka selanjutnya dilakukan uji t. Hasil pengujian hipotesis seperti pada Tabel 1 menunjukkan bahwa nilai $t$ variabel punishment sebesar 3,268 dengan $P$-value (sig) sebesar 0,003 di mana nilai $P$-value tersebut lebih kecil dari taraf signifikansi yang ditentukan yaitu $0,05(0,003<0,05)$ sehingga menunjukkan bahwa nilai $t$ yang diperoleh tersebut signifikan. Maka keputusan uji t yang diperoleh yaitu punishment $\left(\mathrm{X}_{2}\right)$ berpengaruh positif dan signifikan terhadap motivasi kerja (Y). Hal ini berarti bahwa semakin tegasnya punishment yang diberikan kepada karyawan CV Ayudya Tabanan Bali, maka akan semakin meningkatkan motivasi kerja karyawan.

Untuk mengetahui ada atau tidaknya pengaruh antara reward dan punishment terhadap motivasi kerja, maka dilakukan uji $\mathrm{F}$. Hasil pengujian hipotesis seperti pada Tabel 1 menunjukkan bahwa nilai $\mathrm{F}$ sebesar 18,771 dengan $P$-value (sig) sebesar 0,000 di mana nilai tersebut $<0,05$ sehingga keputusan uji $F$ yang diperoleh yaitu hipotesis alternatif diterima, maka reward dan punishment berpengaruh positif dan signifikan terhadap motivasi kerja.

Uji koefisien determinasi dilakukan untuk mengetahui seberapa persen besar sumbangan pengaruh variabel bebas terhadap variabel terikatnya (Priyatno, 2010:66). 
Karena penelitian ini menggunakan regresi dengan dua variabel independen maka koefisien determinasi menggunakan nilai Adjusted $R$ Square (Santoso, 2001). Dari Tabel 1 di atas dapat diketahui bahwa nilai Adjusted $R$ Square sebesar 0,542. Maka dapat disimpulkan bahwa besarnya pengaruh variabel reward dan variabel punishment terhadap variabel motivasi kerja karyawan adalah sebesar $54,2 \%$, sedangkan sisanya $45,8 \%$ dipengaruhi oleh variabel lain yang tidak diteliti dalam penelitian ini.

\section{Pembahasan}

Reward berpengaruh positif dan signifikan terhadap motivasi kerja karyawan pada CV Ayudya Tabanan Bali. Hal itu berarti jika perusahaan meningkatkan reward, maka akan dapat meningkatkan motivasi kerja karyawan. Hasil penelitian ini didukung oleh Merchant \& Stede dalam Kentjana \& Nainggolan (2018), yang menyatakan bahwa reward merupakan hal penting untuk diperhatikan dalam operasional perusahaan karena adanya reward akan mendorong tercapainya hasil kerja yang diinginkan dan memotivasi karyawan untuk bekerja mencapai dan melebihi target.

Temuan studi ini didukung oleh Maria (2010) yang mengatakan sasaran utama pemberian reward adalah menarik orang yang berkualitas untuk bergabung dengan organisasi, mempertahankan karyawan, dan memotivasi karyawan untuk mencapai prestasi kerja yang lebih tinggi. Hal ini sejalan dengan hasil penelitian Sari (2014), Fatmawati (2016), Pratama (2017), Wirawan \& Afani, (2018), Kentjana \& Nainggolan (2018), serta Isnainy \& Nugraha (2018) yang menemukan bahwa penghargaan/reward berpengaruh positif dan signifikan terhadap motivasi kerja.

Reward yang berpengaruh positif terhadap motivasi kerja karyawan pada CV Ayudya Tabanan Bali disebabkan karena apabila dilihat dari deskripsi data yang diperoleh menunjukkan bahwa reward yang diterapkan di CV Ayudya Tabanan Bali sudah mencapai kategori cukup, artinya pemberian reward pada perusahaan tersebut sudah cukup baik bagi sebagian besar karyawan sehingga mampu meningkatkan motivasi kerja karyawan pada CV Ayudya Tabanan Bali. Meskipun berdasarkan wawancara awal (pra penelitian) ditemukan permasalahan terkait reward karena pada saat itu peneliti hanya mendapatkan informasi dari wawancara dengan beberapa karyawan saja. Namun pada kenyataannya setelah dilakukan penelitian ternyata banyak yang menjawab dalam kuesioner bahwa reward di CV Ayudya cukup baik, sedangkan responden yang tidak puas dengan reward di CV Ayudya terdapat sebanyak tiga orang.

Adapun bentuk reward yang ada pada CV Ayudya Tabanan Bali adalah berupa intrinsic reward (penghargaan yang muncul dari perasaan individu itu sendiri) dan ekstrinsic reward (penghargaan yang diperoleh dari orang lain). Adanya pujian (respon positif) dari atasan kepada karyawan pada saat karyawan yang bersangkutan menunjukkan hasil kerja yang memuaskan merupakan salah satu penerapan dari intrinsic reward pada CV Ayudya.

Pemenuhan intrinsic reward juga dapat terlihat saat karyawan diberikan kesempatan untuk belajar hal baru melalui pelatihan atau training bagi karyawan, terutama karyawan produksi. Selain itu, pemenuhan intrinsic reward juga dirasakan saat karyawan CV Ayudya diberikan tanggung jawab yang sesuai dengan bidang pekerjaan mereka dan sesuai dengan kemampuan mereka, sehingga timbul kepuasan dari dalam diri yang memotivasi mereka untuk bekerja dengan baik.

Reward berupa gaji pokok dan upah lembur yang diberikan kepada karyawan yang bekerja di CV Ayudya dianggap sudah cukup baik bagi sebagian besar karyawan. Gaji yang mereka terima dirasa sudah sesuai dengan kontribusi karyawan dalam menaikkan omzet perusahaan. Hal itu menunjukkan bahwa ekstrinsic reward berupa gaji sudah terpenuhi dengan cukup baik dan hal tersebut mampu menimbulkan gairah dalam bekerja sekaligus memotivasi karyawan.

Ekstrinsic reward berupa bonus yang diberikan bagi karyawan CV Ayudya Tabanan Bali dianggap sudah cukup baik bagi sebagian besar karyawan. CV Ayudya akan memberikan bonus setiap bulan apabila karyawan mampu berproduksi mencapai target yang telah ditentukan. Hal itu mampu membuat karyawan termotivasi untuk menunjukkan kemampuan terbaik dan menjadi semakin produktif. 
Ekstrinsic reward berupa tunjangan yang diberikan bagi karyawan CV Ayudya Tabanan Bali dianggap sudah cukup baik. Adapun jenis tunjangan yang diberikan oleh CV Ayudya kepada karyawannya adalah berupa tunjangan jabatan, uang makan, tunjangan kesehatan, tunjangan hari raya, dan uang lembur. Semakin tinggi jabatan seorang karyawan, maka nominal tunjangan yang ia peroleh juga makin besar, sehingga adanya reward berupa tunjangan akan memotivasi karyawan untuk bekerja dengan lebih maksimal agar bisa mencapai posisi jabatan yang lebih tinggi.

Selain itu, CV Ayudya juga memberikan ekstrinsic reward berupa kesempatan naik jabatan atau promosi jabatan. Pemberian promosi jabatan ini tergantung pada kebutuhan perusahaan. Umumnya karyawan yang mendapat kesempatan promosi jabatan dilihat dari seberapa besar kontribusinya dalam mendukung kemajuan perusahaan atau bisa juga dilihat dari senioritas. Adanya kesempatan promosi jabatan tersebut mampu memotivasi karyawan untuk bekerja dengan lebih bersemangat dan lebih loyal kepada perusahaan. Mengingat adanya reward mampu meningkatkan motivasi kerja, oleh karena itu perlu diingat bahwa implementasi pemberian reward di CV Ayudya, perlu dilakukan secara kontinyu, konsisten, dan tepat waktu agar reward tersebut semakin efektif dan bisa meningkatkan motivasi kerja karyawan secara signifikan.

Punishment berpengaruh positif dan signifikan terhadap motivasi kerja karyawan pada CV Ayudya Tabanan Bali. Hal itu berarti jika perusahaan meningkatkan punishment, maka akan dapat meningkatkan motivasi kerja karyawan. Hasil penelitian ini didukung oleh Pratama (2017) yang menyatakan punishment merupakan hal yang berwujud negatif, tetapi bila diberikan secara tepat dan bijaksana akan bisa menjadi alat perangsang bagi karyawan untuk meningkatkan motivasi kerja. Temuan studi ini didukung oleh Sari (2014) yang menyatakan bahwa adanya punishment diharapkan akan mengarahkan/mendidik karyawan kepada perilaku positif dan mendorong adanya motivasi kerja. Hal ini mendukung hasil penelitian Sari (2014), Pratama (2017), Wirawan \& Afani (2018), serta Kentjana \& Nainggolan (2018) yang menemukan bahwa punishment berpengaruh positif dan signifikan terhadap motivasi kerja karyawan.

Apabila dideskripsikan dari data yang diperoleh menunjukkan bahwa punishment yang diterapkan di CV Ayudya Tabanan Bali sudah mencapai kategori cukup baik, artinya pemberian punishment pada perusahaan tersebut dianggap sudah cukup baik bagi sebagian besar karyawan sehingga mampu meningkatkan motivasi kerja karyawan pada CV Ayudya Tabanan Bali.

Punishment yang diterapkan pada CV Ayudya Tabanan Bali mulai dari punishment yang sifatnya preventif (bersifat mencegah) hingga punishment represif (penindakan setelah terjadi pelanggaran) dari hukuman paling ringan hingga paling berat. CV Ayudya sudah memiliki tata tertib serta larangan yang sudah disampaikan kepada karyawan sejak awal mereka diterima bekerja. Hal itu merupakan wujud upaya preventif dari perusahaan untuk mencegah terjadinya kelalaian dan diharapkan agar karyawan bisa lebih termotivasi untuk menunjukkan kedisiplinan dalam bekerja.

Setiap pelanggaran disiplin kerja yang dilakukan oleh karyawan CV Ayudya telah mendapat sanksi yang adil tergantung pada seberapa fatal kesalahan yang dilakukan oleh karyawan. Sanksi (punishment) yang paling ringan adalah berupa teguran yang kepada karyawan secara langsung setelah terjadinya pelanggaran. Dapat pula dilakukan hukuman pemotongan gaji bagi karyawan yang melakukan pelanggaran kategori sedang. Jika terjadi suatu perbuatan pelanggaran berat yang dianggap sangat merugikan perusahaan, maka punishment represif paling berat yang dapat dilakukan adalah pemutusan hubungan kerja (PHK).

Punishment yang bersifat represif tersebut dapat memberikan efek jera bagi karyawan yang lalai dan timbul kesadaran untuk memperbaiki perilaku buruknya ke arah yang lebih positif. Kondisi seperti itu dapat mendorong adanya motivasi kerja dari dalam diri karyawan, di mana karyawan akan menjadi lebih disiplin serta lebih bertanggung jawab dengan tugas atau pekerjaan yang diberikan. Maka dari itu, punishment yang diberikan 
sebaiknya lebih tegas dan disertai dengan penjelasan. Pemberian punishment tersebut haruslah sesegera mungkin dilakukan setelah karyawan membuat sebuah pelanggaran.

Reward dan punishment berpengaruh positif dan signifikan terhadap motivasi kerja karyawan pada CV Ayudya Tabanan Bali. Hal itu berarti reward dan punishment secara bersama-sama mampu memotivasi karyawan untuk meningkatkan kualitas kerjanya. Hasil penelitian ini didukung oleh Kentjana \& Nainggolan (2018) yang mengatakan bahwa reward dan punishment merupakan dua hal yang maknanya berlawanan, namun keduanya mempunyai keterkaitan karena kedua hal itu memotivasi karyawan dalam meningkatkan kualitas saat bekerja. Temuan studi ini juga didukung oleh Husaini Usman dalam Darmadi (2018) yang mengatakan pemberian penghargaan dan sanksi akan dapat menjaga dan meningkatkan motivasi kerja Hasil penelitian ini sejalan dengan penelitian terdahulu yang dilakukan oleh Pratama (2017), Sandy \& Faozen (2017), Wirawan \& Afani (2018), Fajar (2018), serta Kentjana \& Nainggolan, (2018) yang menemukan bahwa reward dan punishment berpengaruh positif dan signifikan terhadap motivasi kerja.

Berdasarkan analisis koefisien determinasi (Adjusted $R$ Square) didapatkan hasil bahwa reward dan punishment memberikan kontribusi pengaruh terhadap motivasi kerja sebesar $54,2 \%$ sedangkan sisanya yaitu sebesar $45,8 \%$ dipengaruhi oleh variabel lain yang tidak dimasukkan ke dalam penelitian ini. Hal itu menunjukkan bahwa pengaruh reward dan punishment terhadap motivasi kerja karyawan pada CV Ayudya Tabanan Bali tergolong tinggi.

Semakin tinggi reward dalam perusahaan, perlu diikuti dengan punishment yang tinggi agar dapat semakin meningkatkan motivasi kerja karyawan. Di mana adanya reward dan punishment yang tinggi akan dapat memotivasi karyawan untuk bekerja mencapai/melebihi target yang ditentukan perusahaan, memotivasi untuk meningkatkan keahlian sesuai bidang pekerjaan yang ditekuni, dan memotivasi untuk menyelesaikan tugas tepat waktu. Oleh karena itu reward dan punishment sama pentingnya untuk dapat meningkatkan motivasi kerja karyawan pada CV Ayudya Tabanan Bali.

\section{Simpulan dan Saran Simpulan}

Berdasarkan hasil penelitian dan pembahasan, dapat ditarik beberapa simpulan sebagai berikut: (1) Reward berpengaruh positif dan signifikan terhadap motivasi kerja karyawan pada CV Ayudya Tabanan Bali. (2) Punishment berpengaruh positif dan signifikan terhadap motivasi kerja karyawan pada CV Ayudya Tabanan Bali. (3) Reward dan Punishment berpengaruh positif dan signifikan terhadap motivasi kerja karyawan pada CV Ayudya Tabanan Bali.

\section{Saran}

Berdasarkan hasil penelitian, pembahasan, dan simpulan yang telah dikemukakan sebelumnya, maka dapat diajukan beberapa saran sebagai berikut: (1) Bagi CV Ayudya Tabanan Bali, diharapkan agar lebih meningkatkan motivasi kerja karyawannya dengan cara mengoptimalkan implementasi sistem pemberian reward yang sesuai dan punishment yang tegas bagi karyawannya. Karena berdasarkan hasil dari penelitian ini terbukti bahwa reward dan punishment dapat mempengaruhi motivasi kerja ke arah yang positif. (2) Bagi peneliti selanjutnya yang tertarik untuk mengkaji aspek yang serupa yaitu reward, punishment, dan motivasi kerja diharapkan untuk mengembangkan penelitian ini dengan menggunakan subjek penelitian yang lebih luas. Selain itu juga diharapkan untuk menambahkan atau menguji variabel lain yang diduga dapat mempengaruhi motivasi kerja karyawan, seperti komunikasi internal, budaya organisasi, karakteristik pemimpin, maupun variabel lainnya yang dapat mempengaruhi motivasi kerja.

\section{Daftar Pustaka}

Darmadi. 2018. Optimalisasi Strategi Pembelajaran. Bogor: Guepedia. 
Fajar, Harini, dkk. 2018. "Pengaruh Pemberian Penghargaan dan Hukuman Terhadap Motivasi Kerja serta Implikasinya pada Kinerja Karyawan PT Difa Kreasi di CikarangBekasi”. Jurnal IImu Manajemen \& Bisnis, Vol 9 No 1 (hlm. 35-43).

Farianda, Isna. 2013. "Pengaruh Mutasi Jabatan dan Penghargaan terhadap Motivasi Kerja Pegawai pada Bagian Umum Sekretariat Daerah Kota Surakarta". Artikel Publikasi IImiah, Fakultas Keguruan dan IImu Pendidikan Universitas Muhammadiyah Surakarta. Tersedia pada http://eprints.ums.ac.id (diakses tanggal 11 Oktober 2019).

Fatmawati, Ana Dwi. 2016. "Hubungan Pemberian Reward Dengan Motivasi Kerja Perawat Pelaksana di Ruang Rawat Inap Kelas III Rumah Sakit Umum Daerah RAA Soewondo Pati. Publikasi ilmiah, Program Studi Keperawatan S1 Fakultas IImu Kesehatan Universitas Muhammadiyah Surakarta. Tersedia pada http://eprints.ums.ac.id (diakses tanggal 9 Oktober 2019).

Isnainy, Usastiawaty Cik Ayu Saadiah dan Andri Nugraha. 2018. "Pengaruh Reward dan Kepuasan Kerja Terhadap Motivasi dan Kinerja Perawat". Holistik Jurnal Kesehatan, Volume 12, No.4 (hlm. 235-243).

Janie, Dyah Nirmala Arum. 2012. Statistik Deskriptif \& Regresi Linier Berganda dengan SPSS. Semarang: Semarang University Press.

Kentjana, Natasya Michelle Putri dan Piter Nainggolan. 2018. "Pengaruh Reward dan Punishment terhadap Kinerja Karyawan dengan Motivasi sebagai Variabel Intervening (Studi Kasus pada PT. Bank Central Asia Tbk.)". National Conference of Creative Industry: Sustainable Tourism Industry for Economic Development Universitas Bunda Mulia, Jakarta (hlm. 973-997).

Manullang dan Marihot AMH Manullang. 2008. Manajemen Personalia. Yogyakarta: UGM Press.

Maria, Evi. 2010. "Hubungan Penghargaan Intrinsik terhadap Motivasi Kerja”. Jurnal Bisnis dan Ekonomi (JBE), Vol.17, No.1 (hlm. 1-9).

Prasetya, GL. Hery. 2017. "Pengaruh Komunikasi Internal, Budaya Organisasi, dan Penghargaan terhadap Motivasi Kerja Karyawan PT. Wahana Wirawan (Dealer Mobil Nissan Tb. Simatupang - Jakarta)". Prosiding Seminar Nasional Inovasi Teknologi SNITek 2017 (hlm. 78-84).

Pratama, Andhika Putra, dkk. 2017. "Pengaruh Reward dan Punishment terhadap Motivasi Kerja Karyawan Goldia Camilan Malang". E-Jurnal Riset Manajemen Prodi Manajemen Fakultas Ekonomi Unisma. Tersedia pada http://riset.unisma.ac.id (diakses tanggal 9 Oktober 2019).

Priyatno, Duwi. 2010. Paham Analisa Statistik Data dengan SPSS. Yogyakarta: Penerbit Mediakom.

Purnomo, Rochmat Aldy. 2016. Analisis Statistik Ekonomi dan Bisnis dengan SPSS. Ponorogo: CV WADE Group.

Sandy, Syah Riza Octavy dan Faozen. 2017. "Pengaruh Reward dan Punishment Serta Rotasi Pekerjaan terhadap Motivasi Kerja untuk Meningkatkan Kinerja Karyawan Hotel di Jember". Jurnal Kepariwisataan dan Hospitalitas Vol. 1, No. 2 (hlm. 134-150).

Santoso, Singgih. 2f001. SPSS 10: Mengolah Data Statistik Secara Profesional. Jakarta: PT Elex Media Komputindo.

Sari, Yuanita Widyanti Sofiana. 2014. "Pengaruh Komunikasi Internal, Reward dan Punisment terhadap Motivasi Kerja Karyawan di BPR Nur Semesta Indah Kencong Kabupaten Jember". Jurnal Ekonomi dan Bisnis. Tersedia pada http://digilib.unmuhjember.ac.id (diakses tanggal 8 Oktober 2019). 
Suliyono, Joko. 2010. 6 Hari Jago SPSS 17. Yogyakarta: Penerbit Cakrawala.

Triyanto, Arif dan Sudarwati. 2014. "Pengaruh Kompetensi dan Penghargaan terhadap Motivasi Kerja Karyawan PT Kai di Stasiun Sragen". Jurnal Paradigma Vol. 12, No. 01 (hlm. 26-40).

Winangsih, Asri. 2017. "Analisis Pengaruh Penghargaan Intrinsik dan Kompensasi terhadap Kinerja Melalui Motivasi Kerja Sebagai Variabel Intervening (Studi Pada Dosen FEB Universitas Muhammadiyah Surakarta)". Publikasi IImiah, Program Studi Manajemen Fakultas Ekonomi dan Bisnis Universitas Muhammadiyah Surakarta. Tersedia pada http://eprints.ums.ac.id (diakses tanggal 11 Oktober 2019).

Wirawan, Adhitomo dan Ismi Nur Afani. 2018. "Pengaruh Reward dan Punishment terhadap Kinerja dan Motivasi Karyawan pada CV Media Kreasi Bangsa". Journal of Applied Business Administration, Vol 2, No 2 (hlm. 76-91)

Yuni, Sri Wisma. 2013. "Pengaruh Tingkat Pendidikan, Pelatihan dan Instrinsic Reward terhadap Motivasi Kerja (Studi Empiris: Pegawai Badan Kepegawaian Daerah Kota Pariaman)". Artikel, Program Pasca Sarjana Magister Sains Manajemen Universitas Bung Hatta. Tersedia pada http://ejurnal.bunghatta.ac.id (diakses tanggal 11 Oktober 2019). 